$0 \quad$ Authors Queries

Journal: Compare

Paper: 286179

Title: Intercultural education and curricular diversification: the case of the Ecuadorian Intercultural Bilingual Education Model (MOSEIB) ${ }^{1}$

Dear Author

During the preparation of your manuscript for publication, the questions listed below have arisen. Please attend to these matters and return this form with your proof. Many thanks for your assistance

\begin{tabular}{|c|c|c|}
\hline $\begin{array}{l}\text { Query } \\
\text { Reference }\end{array}$ & Query & Remarks \\
\hline 1 & $\begin{array}{l}\text { Nationality has a very specific } \\
\text { meaning, i.e. a member of a } \\
\text { nation state. All peoples in } \\
\text { Ecuador have the same nation- } \\
\text { ality, Ecuadorean. They may, } \\
\text { however, belong to different } \\
\text { ethnic, linguistic or tribal } \\
\text { groups. I have used 'ethnic } \\
\text { group'. O.K? }\end{array}$ & \\
\hline 2 & $\begin{array}{l}\text { I am not sure what is meant by } \\
\text { 'arts and offices'. Arts are such } \\
\text { as painting and music. Do you } \\
\text { mean crafts, such as wood- } \\
\text { work? Offices are settled } \\
\text { employment. Please clarify. }\end{array}$ & \\
\hline 3 & $\begin{array}{l}\text { I am not sure that the condi- } \\
\text { tions here conform to the cri- } \\
\text { teria for a bouble bind as } \\
\text { proposed by Bateson. }\end{array}$ & \\
\hline 4 & $\begin{array}{l}\text { I am not sure what is meant by } \\
\text { 'dependencies in many } \\
\text { scopes'. Scope generally } \\
\text { means 'room for action'. } \\
\text { Please clarify. }\end{array}$ & \\
\hline 5 & $\begin{array}{l}\text { Is this DINEIB 2005a or } \\
\text { 2005b? }\end{array}$ & \\
\hline 6 & Is this DINEIB $2005 a$ or $2005 b$ & \\
\hline 7 & $\begin{array}{l}\text { Zimmerman } 2001 \text { here, } 2000 \text { in } \\
\text { References. Which is correct? }\end{array}$ & \\
\hline
\end{tabular}




\begin{tabular}{|c|c|c|}
\hline \multirow[b]{2}{*}{$\begin{array}{l}\boldsymbol{\infty} \\
\boldsymbol{\infty} \\
\boldsymbol{\infty}\end{array}$} & 8 & $\begin{array}{l}\text { I am not sure what is meant by } \\
\text { 'requiring their technical assis- } \\
\text { tance' in this context. Please } \\
\text { clarify. }\end{array}$ \\
\hline & 9 & $\begin{array}{l}\text { I am unsure about the word } \\
\text { 'radiophonic' here. It does not } \\
\text { mean using a radio but des- } \\
\text { cibes a sound made electro- } \\
\text { nically. Please clarify. }\end{array}$ \\
\hline 10 & 10 & $\begin{array}{l}\text { I am unsure how an ethnic } \\
\text { group can be defined as 'a } \\
\text { process of reconstruction and } \\
\text { identity precision'. Please clar- } \\
\text { ify. }\end{array}$ \\
\hline 15 & 11 & Please give PNB in full. \\
\hline 20 & 12 & $\begin{array}{l}\text { Was this presented at a named } \\
\text { Meeting/Conference or similar. } \\
\text { If so please supply title. Please } \\
\text { supply date(s). }\end{array}$ \\
\hline 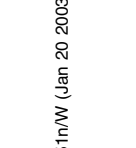 & 13 & $\begin{array}{l}\text { Please supply volume number. } \\
\text { If this journal does not use } \\
\text { volume numbers use year. }\end{array}$ \\
\hline 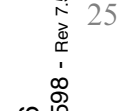 & 14 & $\begin{array}{l}\text { Please supply place of publica- } \\
\text { tion. }\end{array}$ \\
\hline 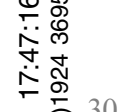 & 15 & $\begin{array}{l}\text { Please supply place (town/city) } \\
\text { of publication. }\end{array}$ \\
\hline 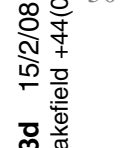 & 16 & $\begin{array}{l}\text { Mazaquisa } 2001 \text { is not cited in } \\
\text { text. Please insert relevant text } \\
\text { citation or delete reference. }\end{array}$ \\
\hline 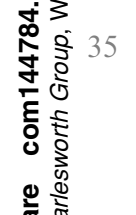 & 17 & $\begin{array}{l}\text { Ministry of Education and } \\
\text { Culture of Ecuador } 1993 \text { is } \\
\text { not cited in text. Please insert } \\
\text { relevant text citation or delete } \\
\text { reference. }\end{array}$ \\
\hline 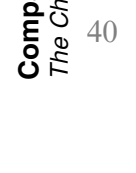 & 18 & $\begin{array}{l}\text { Rambla \& Bonal } 2005 \text { is not } \\
\text { cited in text. Please insert } \\
\text { relevant text citation or delete } \\
\text { reference. }\end{array}$ \\
\hline 45 & 19 & What does 'T. II.' signify? \\
\hline
\end{tabular}




\begin{tabular}{|l|l|l|l|}
\hline \multicolumn{2}{|l|}{20} & $\begin{array}{l}\text { Please supply date(s) of meet- } \\
\text { ing. }\end{array}$ & \\
\cline { 2 - 5 } & 20 & $\begin{array}{l}\text { Please supply date(s) of meet- } \\
\text { ing. }\end{array}$ & \\
\cline { 2 - 5 } & 21 & $\begin{array}{l}\text { Please supply town/city in } \\
\text { which meeting held. }\end{array}$ & \\
\cline { 2 - 5 } & 21 & $\begin{array}{l}\text { Please supply town/city in } \\
\text { which meeting held. }\end{array}$ & \\
\cline { 2 - 5 } & 22 & $\begin{array}{l}\text { Sleeter \& Stillman } 2005 \text { is not } \\
\text { cited in text. Please insert } \\
\text { relevant text citation or delete } \\
\text { reference. }\end{array}$ & \\
\cline { 2 - 5 } & $\begin{array}{l}\text { Stoll 2002 is not cited in text. } \\
\text { Please insert relevant text cita- } \\
\text { tion or delete reference. }\end{array}$ & \\
\hline
\end{tabular}




\title{
Intercultural education and curricular diversification: the case of the Ecuadorian Intercultural Bilingual Education Model (MOSEIB) ${ }^{1}$
}

\author{
Alexis Oviedo* and Danny Wildemeersch \\ Centre for Comparartive, Intercultural and Development Education, Katholieke Universiteit, \\ Leuven, Belgium
}

Thirteen Ecuadorean indigenous ethnic groups follow the Intercultural Bilingual Education Model in Ecuador (MOSEIB). This paper analyses the present situation of MOSEIB, the challenges to it and future prospects. First, in order to understand how MOSEIB today has relieved the intercultural tensions of the past it is necessary to look at the history of Ecuadorian education. Second, in order to explore the particular characteristics of the MOSEIB model and the challenges of implementing intercultural education in non-intercultural societies we ask how and to what extent the intercultural education policies and practices in Ecuador differ from those developed in other Latin-American countries. Third, we consider curricular diversity, seeking to clarify how the MOSEIB curricula relate to the reality of Kichwa indigenous ethnic group and its communal environment, rituals and agricultural schedules. We conclude with comments on future prospects and remaining challenges to the establishment of a truly intercultural society inside a multicultural country.

Keywords: intercultural education; curricular diversification

\section{Introduction}

The recent presidential elections in Bolivia brought Evo Morales to power. He is the first native American elected as a president in a Latin-American country in the history of the continent. This event definitely marks a change in the traditional power structure, because whites and white-mestizos ${ }^{2}$ have ruled Latin-America since the European invasion in 1492. Five hundred and fourteen years were needed for one of the descendants of the first settlers of the continent now called America to rule one of its countries. During these 514 years Latin-America has been co-inhabited by native Americans, ${ }^{3}$ blacks and white-mestizos. Colonization meant that the latter enslaved and exploited the native Americans and the blacks, intending also to impose their culture, while systematically denying the indigenous historical background.

The aim of this paper is to give an overview of how education today deals with this historical heritage. It analyses the educational policies concerning the Ecuadorian indigenous peoples today, in particular the development of the Ecuadorian Intercultural Bilingual Educational Model (Modelo del Sistema de Educación Bilingüe, MOSEIB), drawing mainly on the publications of indigenous organizations and indigenous educational thinkers as our primary data sources. 
0 The colonial legacy: intercultural tensions in the school system

Ecuador is ethnically speaking a complex society with a long history of intercultural tension. The fact that it is very hard to define precisely who belongs to what category of the population reflects this complexity. Counting the numbers inevitably is a controversial and political matter, leading to various results, depending on who does the calculations. The 2001 official census determined that 830,418 persons declared themselves to be native Americans. This represents $6.83 \%$ of the $12,156,608$ Ecuadoreans. In contrast to this, the Confederation of Indigenous Nationalities of Ecuador (Confederación de Nacionalidades Indígenas del Ecuador, CONAIE) in 1989 counted 3,111,600 native Americans, which represents 35\% of the national population (CONAIE 1989). The Unit of Indigenous Peoples and Community Development of the Inter American Development Bank estimated in 1990 that the indigenous Ecuadorean population represented $25 \%$ of the total number of Ecuadoreans. These quantitative estimations reflect the political dimensions of the existing power relations. However, none of those estimations have a very solid empirical basis. Social research, using diverse methodologies, has shown that the indigenous Ecuadorean population oscillates between 8 and $12 \%$ of the total number of inhabitants (Comisión Económica par América Latina y el Caribe [CEPAL] 2005, 18-22).

The different interpretations of 'who is who' in Ecuador go back to a long history of inclusions and exclusions, starting in the 15th century with the European invasions. The tensions between the dominant white-mestizo group and the marginalized indigenous cultures have also been reflected in the school system. Historically the school has been a combined instrument of 'indoctrination' and 'civilization'. In Latin-America the school additionally had the role of dragging the new colonies into the modern world (Garcés and Guzmán 2003). During the European colonization the school was the principal instrument of subjection of the indigenous peoples to the demands of the rulers. Thus, the history of Ecuadorean education began with schools created to spread Hispanic catholic values, principles and lifestyles among the native Americans. Later on, during the consolidation of colonial power, the school was transformed into an institution to discipline and dominate the indigenous peoples. In the colonial period the caste structure determined access to education in general and to school in particular. Thus, rich white children received a home education, while poor white children went to school. Mestizos generally did not send their children to school. Those children who actually managed to access school were accepted in one of the charity schools under the auspices of the church and were forbidden access to university. Native Americans and blacks did not have the right to go to school. Some of the former were trained in 'arts and offices', while the latter were slaves (Roig 1984). Together with the birth of the new republic in 1830, and during the writing of the constitution and consolidation of the new state, the school was used to promote assimilation of indigenous peoples as part of a homogenization process, useful in the construction of a nation state.

School and education in general played an important role in creating a double bind. On behalf of official institutions it created the conditions to incorporate indigenous groups into the system. Simultaneously, it offered opportunities for native Americans to achieve some civil rights, to acquire recognition as citizens and to obtain the necessary background to better relate to the dominant mestizo-Hispanic 
society. It is not surprising that historically indigenous peoples demanded of the Ecuadorean state the right to be educated and to be allowed to enrol in Hispanic schools (López and Küper 2004). Later, indigenous peoples came to consider that this type of school did not meet their cultural aspirations. Nor did it achieve the sought social change and expected progress. Thus they set up a new type of school, in accordance with their cosmological vision.

In the middle of the 20th century, in 1945, three indigenous schools began operations close to Quito, the Ecuadorean capital, under the leadership of Dolores Cacuango, an indigenous leader who had dedicated her life to defending the Kichwa language and land tenure rights. However, 'under the pressure of big landowners (terratenientes), together with a government that saw a 'communist focus' in these schools, education for native Americans was rejected. 'In 1963, the military government, ... closed the last school and forbade the use of Kichwa for the instruction of the children' (EduFuturo 2005, 1).

However, from 1960 onwards new educational experiences have been developed. Most of them involve community participation ${ }^{5}$ and were set up within a framework of experimental projects and programmes developed with the help of foreign partners (López and Küper 2004). Indeed, the origins of intercultural educational programmes in all Latin-American countries were set up in such a way with the exception of Mexico, which developed bilingual and bicultural experiments on the initiative of the Ministry of Education. ${ }^{6}$ The biggest programme in Ecuador was The Research Centre for Indigenous Education (CIEI), which had 724 adult education centres and 300 schools for children, being also one of the first to produce reading materials in indigenous languages. In almost all of the programmes mentioned above community participation was decisive in terms of policy definition and teacher selection (Montaluisa n.d.).

However, ancient tensions remain, as Rosa Maria Torres, ex-minister of Education commented. According to her national policy as well as the practice of intercultural bilingual education continue to operate in the shadow of Hispanic education. 'State support has always been limited, forcing indigenous education to become strongly dependent on external financing, which creates dependencies in many scopes' (Torres 2005, 24).

\section{MOSEIB: towards an Ecuadorean model for intercultural bilingual education}

In recent years the claims of indigenous movements, together with gradually shifting political power relations, have led to an acknowledgement of the need for a profound change in the educational system. The Ecuadorean model for Intercultural Bilingual Education (MOSEIB) is the result of this shift. It has reached a very important goal that moves it beyond the level of other Latin-American countries. 'In legal and administrative terms the Ecuadorean case has showns itself to be totally special within the Latin-American context. It is the only country with a parallel educational system whose task it is to look after the indigenous population' (Garcés 2004, 6). Ecuadorean bilingual intercultural education can be considered the main achievement of the Ecuadorean indigenous peoples in terms of cultural rights recognition.

MOSEIB is the curricular model used by the National Directorate of Bilingual Intercultural Education (DINEIB), which provides schooling for 13 indigenous ethnic groups within Ecuador, ${ }^{7}$ the largest of which is Kichwa. MOSEIB originated 
0 from the official recognition of bilingual intercultural education in 1989, with the primary aim of revaluing indigenous knowledge and languages. Nowadays both the 'Hispanic' educational system, thus named because it serves the white-mestizo population, and MOSEIB together form the basis of the Ecuadorean curricular system.

Historically indigenous peoples wanted to obtain from the Ecuadorean state the right to learn both in their own language and in accordance with their cosmological vision and knowledge base. Bilingual intercultural education (educación intercultural bilingüe) emphasizes an education based on the use of native languages as part of a process of cultural and linguistic reinforcement. Bilingual intercultural education was initiated to 'promote the re-evaluation and recovery of the cultures and indigenous languages of the diverse ethnic groups and peoples' (Instituto Científico de Culturas Indígenas [ICCI] 2001, 1). At the time indigenous peoples in Ecuador considered that the rich diversity of indigenous cultures was rapidly disappearing. The Confederation of Indigenous Nationalities of Ecuador (CONAIE) completed the proposals for intercultural bilingual pducation in 1988. In 1989 the Ministry of Education and CONAIE signed an agreement, placing the responsibility for bilingual intercultural education on the indigenous organization and creating the DINEIB, a department of the Ministry of Education. The result is that the Ecuadorean Ministry of Education currently provides two separate educational systems: one Hispanic and one indigenous.

In 1993 MOSEIB was legally and officially recognized by the Ministry of Education of Ecuador as a 'global curricular proposal for the model, that contains principles, aims, objectives, strategies of implementation, a curricular basis (actors, general principles, methodology, chronology, educative levels, modalities, teaching, monitoring and evaluation) and study programs' (Garcés 2004, 8). Later on the aim was extended to offer to native groups their own knowledge in combination with universal knowledge (Quishpe Lema 2001), using both their original language and the Spanish language in a bilingual context. Linguistic matters play a central role in the model. The correct use of indigenous languages and their grammatical and written development are important aspects of this curricular proposal, because indigenous languages are the main instrument of learning and communication for the native ethnic groups. 'Language is a unique manifestation of the feelings of the person, ... therefore, it is pertinent to develop it suitably; in this way each of the indigenous languages of Ecuador will be an instrument for education, just as the Spanish language is' (Quishpe Lema 2001, 2). In line with this aim EIB systematized and standardized 13 indigenous languages within Ecuador. Today the indigenous ethnic groups are able to develop their own educational curricula and pedagogical processes in their own language and cultural context (DINEIB 2005). Spanish, in line with the bilingual character of the proposal, is conceived of as a second language. As such, it is also the language of intercultural relationships.

Nowadays MOSEIB is operational in 1908 schools, employing 5617 teachers (Garcés 2004, 10-2). The model serves 103,425 indigenous students (DINEIB 2005). The Intercultural Bilingual Education System, as part of its curricular diversification process, seeks to replace Hispanic school practices within Community Education Centres (CIEIBs) for all indigenous ethnic groups. The CIEIBs differ from traditional schools in that their main purpose is to support the educational development of the whole community in which they are located. ${ }^{8}$ This implies the 
construction of educational curricula for each of the 28 peoples forming the 13 different ethnic groups. In principle this should involve the active participation of parents, community and educational leaders, teachers and national and international organisations in the educational process (Oviedo 2004).

Together with implementation of the model, fairly new and advanced constructionist visions and principles of teaching and learning have been introduced, in combination with an emphasis on indigenous traditions, including non-western cosmologies. At the level of intentions there is a strong emphasis on self-direction by the learner, on learning based on a combination of experimentation and experience and on societal relevance through an effective embedding of the learning in communal and family practices. In line with this, MOSEIB has developed a methodological cycle which helps the teacher and the learner to organize their daily learning practice (Quishpe Lema 2001, 4).

In the organization of the learning process MOSEIB uses a methodology in which experimentation and experience - in accordance with indigenous traditions are considered to be the axis of knowing. In doing so it distances itself from western academic epistemology. When analysing specific methodological implementation it is important to stress that MOSEIB practice takes the previous knowledge of the student as a starting point. Learning, therefore, does not begin in school. It is an activity that is strongly related to the communal and family life and background. This strong vernacular orientation is expected to provide increased self-confidence in indigenous students.

Research is the principal instrument of the learning process, both at school and in the community. Within school, group research and self-research are the methodological tools for student learning. At the community level it is the collective process of learning enrichment that matters. The community is the setting that consolidates the learning process, through valuing and validation of the outcomes achieved by the student in their learning. Communal participation legitimates knowledge production and reproduction and also looks to achieve a knowledge that can be useful in communal life, while at the same time allowing the rescue and reinforcement of traditional practices.

Observation of some schools applying MOSEIB $^{9}$ indicates that communal interaction in the educational process may also permit an improvement in relations between the family and the school, as well as the creation of horizontal relations between teachers and students. The learning process is conceived as a dialogical one, which enables the development of democratic relationships among the actors, neutralizing the traditional hierarchical teacher-student relationship.

\section{Intercultural education in 'non-intercultural societies'}

Ecuadorean society is multicultural, due to the presence of different ethnic groups that have settled in the country over time. However, a multicultural society is not necessarily an intercultural society. As Schmelkes (2005) noted, a multicultural society can also be a racist society. According to this author the concept of interculturality is more an aspiration to be achieved. Schmelkes preferred to talk about education for interculturality rather than about intercultural education, because the achievement of intercultural education means avoiding asymmetries among cultural groups. The relations among different cultural groups must be based 
0 on respect and egalitarian attitudes, denying attitudes of cultural superiority by one of those groups, often related to racism. Therefore, in the context of a country, interculturality must necessarily be exercised simultaneously by the hegemonic culture and by the minority cultures (Schmelkes 2005).

Under these conditions it is hard to realize an effective intercultural education, as long as white-mestizo subjectivities still reflect racist perceptions of superiority. In spite of the official recognition of MOSEIB, the implementation of an effective intercultural process in Ecuador still has a long way to go. In fact, the intercultural project must be based on the principle of genuine cultural exchange and on the practice of 'two way' conscious actions by the different cultural actors. Such principles and practices have not yet been achieved. Bilateral dialogue is not yet possible because white-mestizo society creates subtle barriers. Luis Montaluisa, one of the historic indigenous drivers of intercultural education, explained his point of view on the difficulty of achieving an intercultural relationship at the present time as follows: 'It seems to be that scorn for the native remains in the unconscious side of 15 society. Maybe after two generations, racism will still remain. The main impediment to interculturality is ignorance of the other and racism' (Montaluisa n.d., 9). Moreover, an analysis of the formal education system shows that intercultural education mainly remains restricted to declarations in official documents. Interculturality is not practiced in daily curricular activities in the classroom. A 20 major reason for such shortcomings is that the Hispanic curriculum reflects in different ways, even in school textbooks, the assumption that western knowledge is superior to indigenous knowledge. ${ }^{10}$

The lack of a real practice of interculturality is not only an exclusive phenomenon of Ecuador. It is also present in other countries of South America. An analysis of different educational realities in various countries that have a considerable majority ${ }^{11}$ indigenous populations shows that interculturality among the white-mestizos and indigenous groups is not taken for granted within them.

In Bolivia $67 \%$ of the total population is indigenous. It has developed its own model of intercultural bilingual education. The Bolivian state had historically sought to 'erase' differences between indigenous peoples and the white-mestizos, by a process of campesinización, which invited native Americans to forget their ethnicity, their Aymara, Guarani or Kechwa roots (Comboni and Juárez 2001), while adopting the identity of peasants. Today, Bolivian reform is very similar to the Ecuadorean one. A first similarity is the fact that Kechwa is the largest indigenous ethnic group in both countries. Another similarity is that both educational reforms are aimed at instituting the exercise of linguistic and cultural rights. The basic elements of the Bolivian reform are identity and cultural diversity, while the objectives of Ecuadorean MOSEIB are interculturality, cultural identity and an improvement in the conditions of indigenous peoples. A specific department within the Ministry of Education develops the institutional implementation of bilingual intercultural education in both countries. Indigenous organizations from both countries have developed collaborative activities and Bolivian and Ecuadorean technicians within the respective bilingual intercultural education departments share experiences.

In the case of Mexico non-interculturality is manifest in asymmetries within the school system. Various indices of educational quality are significantly lower for the indigenous population. Apart from that, the cultural majority still considers the indigenous peoples as culturally inferior. Against this backdrop, the Mexican state 
has used the term 'intercultural bilingual education' to designate a bilingual educational modality intended exclusively for the indigenous population. According to Schmelkes this is wrong, because 'intercultural education' should address the entire population. 'If intercultural education is not for all, then it cannot be called intercultural' (Schmelkes 2005, 8).

Intercultural processes and bilingual education in Latin-America have probably reached their highest level in Guatemala. While a few years ago the government supported genocide of the indigenous population, nowadays the state recognizes the educational rights of Guatemalan indigenous peoples. Indeed, in this small country bilingual intercultural education is one of the results of a restorative justice process established after the peace agreements of 1996, aimed at putting an end to the genocide that caused indigenous peoples to suffer under the military government.

[It] is necessary to remember, that ... the mere mentioning of bilingualism, was dangerous for teachers. In fact, many bilingual teachers, even without being supporters of the guerrillas, were persecuted, kidnapped, and murdered ... as was the case of the Tz'utujiles de Sololá. (Moya 2000)

Although the agreements on Guatemalan educational reform have been operational since 1997 the white-mestizo population and even some sectors of indigenous peoples are uninterested in rescuing Maya spirituality and its vernacular knowledge. That is why programmes that promote intercultural processes for the whole population are compulsory and considered more urgent than processes of curricular reform. Hence, in monolingual Hispanic schools the inclusion of Maya content as well as teaching of the local Maya language is at stake (Moya 2000).

Paraguay seems to be the only case where the constitution recognizes the existence of two official languages: Guarani and Spanish. Yet, in spite of the fact that the majority of the Paraguayan population, belonging to very different social backgrounds, speaks both languages (López and Küper 2004), this does not mean that the indigenous language has official symbolic and administrative presence (PROEIB Andes n.d.).

To conclude, it should be mentioned that the experiments in intercultural bilingual education in Latin-America began with financial support from foreign donors, through development programmes and research projects. Mexico is the only exception, as the state created a public department to provide 'bicultural and bilingual education to the ethnic groups' (Carrasco 2003, 2). However, it is clear that states and societies in the Latin-American context still conceive of bilingual intercultural education in terms of a handful of proposals in favour of native Americans. It is not yet considered an invigorating political proposal for the whole Bolivian, Mexican, Ecuadorean or other Latin-American nation. It is definitely necessary to include the creation of an education process within a framework of 'two way bilingualism' (Comboni and Juárez 2001), a task that if not taken up by the state must be developed by society in general. Stimulating the learning of indigenous languages by the white-mestizo and white populations will contribute decisively to the valorization of an indigenous cultural matrix, which can guarantee peace and harmony eithin a multi-ethnic and democratic society. In societies which have one strong language and many weak ones (sociedades diglósicas) it is the right of indigenous peoples to receive an education in their own language (Comboni and Juárez 2001; Schmelkes 2002). In the Latin-American context it is necessary to 
0 transform the attitudes and behaviour of Spanish speakers in their relation to indigenous cultures. This attitudinal change will make a valid contribution to cohabitation and to the existence of interculturality in a multilingual society. Moreover, when the state develops discriminatory educational policies it is the task of social movements to establish dialogues and develop actions for interculturality within society as a whole as part of their contribution to the democratization of society.

\section{How to diversify curricula for Kichwa rural communities?}

10 The elements mentioned above show that agents of intercultural curricular reform should take into consideration language aspects as well as communal aspects. With regard to both aspects, various Latin-American perspectives and critiques have been developed in recent times.

Zimmerman (2001) supported an integrative approach concerning the linguistic aspects of the curriculum when referring to the Guatemalan experience. He suggested that it is not sufficient to start with a course in the indigenous language. It is also important to teach the academic subject matter in that language. Yet there are limitations.

Such an objective can be easily carried out in subject matter such as social sciences or modules of practical units ..., as well as in musical and artistic education. Nevertheless, it would be very difficult or almost impossible to put it into practice in the natural sciences. (Zimmerman 2001, 12)

Moreover, with regard to the learning of languages he argued that it is imperative to include metalinguistic elements.

Because only an explicit presentation of the facts can contribute to a growing awareness of the intercultural situation, and of the value of each element of the cultures that are implied in daily life, [a life] that is characterized by interculturality. (Zimmerman 2001, 14)

Other researchers have also valued the inclusion of elements of ethno-education, mainly in the learning of mathematics.

With regard to the communal aspects of curricular diversification in rural schools the experiences and curricular appraisals developed in Bolivian and Guatemalan $^{12}$ community education are inspiring. The Bolivian experience of curricular diversification, for instance, started with a process of self-investigation of communal life and Kechwa knowledge, including ongoing participation by the community in the control of educational development, not only with regard to content but also to the training of students in skills useful for communal improvement. Curricular diversification is based on a specific perception of research: 'Andean research, as distinguished from western academic research, is a collective research based on experience and experimentation, which are transmitted orally' (Garcés and Guzmán 2003, 79).

Garcés and Guzmán considered the following main strategies to strengthen community research and, therefore, curricular diversification:

- permanent respect for the ritual agricultural calendar, the social space and the scope of knowledge to be researched; 
- definition of the actors who will carry out investigations, with the active participation of the entire community, including in terms of resources;

- using a flexible methodology according to schedules established by the community and directly related to the strategic political project of the Kichwa people and to the particular community project.

These strategies are intended to strengthen cultural identity and local organization (Garcés and Guzmán 2003). Curricular diversification can also influence processes of communal dialogue and discussions about the necessary flexibility of schools in an agrarian society, as well as about reform of the methodological process of selflearning and pedagogical mediation, ${ }^{13}$ elements that have already demonstrated their relevance and cost-effectiveness in other educational contexts. ${ }^{14}$

\section{Weaknesses which MOSEIB still has to overcome}

In spite of the positive results achieved, such as its official recognition as a national educational model and its innovative methodology, MOSEIB still has problems. These vary from misunderstandings in the application of the methodological phases, mentioned above, to a lack of government funds and interference by government Hispanic curricular authorities. The problems analysed here are drawn from those formulated by indigenous organizations, CONAIE and The National Federation of Farmers, Indigenous and Black Organizations (FENOCIN) ${ }^{15}$ being the two most important indigenous organizations. These are supplemented by the comments and perspectives of diverse indigenous leaders and thinkers. Some aspects mentioned in Garcés' (2004) evaluation of MOSEIB are also considered.

CONAIE considers that the Hispanic Directorate of Education dominates bilingual intercultural education, arguing that indigenous bilingual intercultural education is a mere translation of the Spanish model. As such, bilingual intercultural education does not start from the cosmological vision, values and practices of the peoples and the ethnic groups. It is also argued that bilingual intercultural education has not considered the possibility of implementing cultural exchange among the ethnic groups and the peoples of the three different geographic zones. ${ }^{16}$ This lack of exchange may reinforce regionalism and may contribute to the division of indigenous organizations.

Additionally, a lack of self-recognition by teachers of indigenous nationality impedes reproduction of the pedagogical system by the communities themselves. Not enough importance is given to education by local organizations. Indigenous congresses, where all the ethnic groups are represented, do not attach much importance to either the promotion of programmes in the mother tongue or to projects designed to improve the quality and infrastructure of indigenous schools (CONAIE 2005).

FENOCIN has argued that the principal problems of bilingual intercultural education are related to institutional practice, pedagogical practice and intercultural issues (FENOCIN 2004, 3).

1. There is a weakness in the participative character and a lack of presence of national organizations.

2. There are institutional weaknesses in the application of MOSEIB, as well as in the human capital in charge of its management. 
3. There is a lack of resources and continuing foreign dependency.

4. There is an ethnocentric vision which risks developing pseudo-academic practices, an approach focused on just one social sector with a weak intercultural vision.

5. There is no institutional recognition of bilingual intercultural education in the country or among its key organizations.

Other indigenous organizations also consider the lack of human resources to be a weakness of MOSEIB. The Confederation of Kichwa Nationalities and Peoples (ECUARUNARI) has asserted that 'teachers do not have enough training in intercultural pedagogy and not enough engagement with the integral formation of students' (ECUARUNARI n.d., 6). Moreover, they criticize the fact that in the indigenous schools teachers and students do not speak either the indigenous language nor Spanish correctly, but mix them (Quishpe Lema 2001).

The role played by parents and indigenous families also contributes to the incorrect application of MOSEIB. ECUARUNARI considers that parents do not participate in the educational process and do not assume their responsibility to educate their children, leaving education exclusively to the school and its teachers (ECUARUNARI n.d., 5). Indigenous linguists, such as Martina Masaquiza and Quishpe Lema, have argued that, as a consequence of educational globalization, there is a conscious attitude by indigenous families of refusing to let their children become confused by a bilingual intercultural education (Quishpe Lema 2001), even though 'some parents, in general, do not understand the approach and the modality of bilingual intercultural education' (Garcés 2004, 32). These parents consider Spanish and white-mestizo culture the best guarantee of social progress (Masaquiza 2001). Moreover, Haboud has shown how Spanish is displacing Kichwa in the family environment, while it may still be used in community activities (Haboud, cited in Garcés 2004).

The role of the state in assuming responsibility for bilingual intercultural education has negatively influenced MOSEIB. First, there is a lack of economic resources assigned to bilingual education. An analysis of social investment has shown that the resources assigned by the Ecuadorean state for social policies decrease every year ${ }^{17}$ and, consequently, educational conditions are poor. The statistics also make clear that bilingual education gets fewer economic resources than the Hispanic model. For instance, in 2004 for basic education the government assigned $\$ 148$ for every student in the Hispanic system, while it assigned $\$ 133$ for every indigenous student (Torres 2005). With regard to basic education, the Ecuadoriean state invests $10 \%$ less in education of the indigenous population than in that of the white-mestizo population. In secondary education the difference is $40 \%$. And recent estimations show that this gap is tending to increase (Torres 2005). This is manifest in different ways. First, there are insufficient bilingual teachers to service the indigenous school population. In several cases, when a new post is created it is assigned to a white-mestizo teacher, but after some years they are allowed to move to the Hispanic system, leaving the indigenous schools understaffed. Second, the state does not support the training of bilingual teachers. While, on the one hand, the state has given credibility to MOSEIB, on the other, there is permanent tension with MOSEIB, because of its opposition to educational and cultural homogenization. This has to do with the role of 'the Hispanic Educational System that, due to its alignment with educational globalization, attracts indigenous students, with the 
support of some authorities who are opposed to the Bilingual Intercultural System' (Oviedo 2004, 19). Finally, the state's attitude is also manifest in the lack of support it gives to the production of textbooks in indigenous languages, which forces indigenous teachers to borrow books from the Hispanic education system, mainly for the first years of basic education.

Rural education and, particularly, indigenous education have specific characteristics that influence low educational results. The rural economy is based on agricultural activities which do not provide sufficient resources for rural families, because of decreasing soil fertility and of neo-liberal policies affecting the general structure of the rural agricultural sector. Consequently, entire families migrate to neighbouring towns to look for agricultural labour. ${ }^{18}$ They also migrate to the larger cities, affecting their childrens' attendance at school. A combination of the factors mentioned above is probably the reason why $6.68 \%$ of the total number of children enrolled in bilingual intercultural education schools in the academic year 2003-2004 dropped out (ECUARUNARI n.d., 2).

\section{Future prospects and challenges}

What are the future prospects for bilingual intercultural education and MOSEIB? The arguments put forward in the preceding paragraphs outline the challenges to be addressed in order to improve MOSEIB and bilingual education in general.

In spite of the problems mentioned, several actions have been taken to improve the situation. Examples are the 'translation of bilingual intercultural education into a curriculum and into concrete materials, as well as the development of models of management, evaluation, training and information' (Torres 2005, 24). Within the framework of MOSEIB material has been produced to support teacher's activities, such as games stimulating language learning, material to develop logical and mathematical thinking and texts to learn Kichwa as a second language (Garcés 2004).

November 2005 was the seventeenth 'official birthday' of intercultural bilingual education in Ecuador. Before and after this anniversary different indigenous organizations ${ }^{19}$ and indigenous thinkers presented their perspectives on bilingual intercultural education to the DINEIB administrators and to the community in general.

FENOCIN (2004) pointed out the main strategic areas and operational directions.

- The institutional defence and political strength of bilingual intercultural education: actions directed at the reconstruction of communal participation entailing organizational commitments and including mobilization.

- The technical and administrative reorganization of bilingual intercultural education: the establishment of community plans on different levels; a national bilingual intercultural education development plan, an operational one and a professional training platform. This strategy would improve the application of MOSEIB and consolidate bilingual intercultural education institutionally in pedagogical, administrative and financial terms.

- The national positioning and recognition of bilingual intercultural education within the state: reformation of the legal framework, articulation with international partners and the promotion of indigenous knowledge at the 
international and national levels. They want to consolidate bilingual intercultural education as a state policy and a theme of the social agenda of the Ecuadorean state.

- The social strength of and community participation in bilingual intercultural education: the incorporation of local education plans into the DINEIB platform and the redistribution of resources, as well as organizational compromises to improve the implementation of the educational proposal at the local level. It can achieve a measurable organizational empowerment.

CONAIE has emphasized the organizational control and professional improvement of human resources. For this purpose they consider it necessary to articulate a new professional evaluation for all DINEIB professionals, encouraging them to complete higher academic studies, as well as requiring their technical assistance in communal schools (CONAIE and Pujupat 2005). Generally, ECUARUNARI shares the views of the organizations mentioned above. However, it has also expressed concerns about a lack of training in intercultural pedagogy and their commitment to the integrated development of students' (ECUARUNARI n.d.).

Historical leaders and thinkers in indigenous education have also raised their voices concerning the destiny of bilingual intercultural education and MOSEIB. For Luis Montaluisa the main concerns around bilingual education nowadays relate to its strategic vision. A long-term vision is necessary which involves responsibility by the entire indigenous society. Communities and their leaders must also adopt this responsible vision as a basic aspect of their world-view. This implies an ongoingt incentive within families aimed at transmitting traditional knowledge to their children, in addition to the promotion of reading and writing skills.

$\mathrm{He}$ is also worried about the fact that only half of the 5000 indigenous teachers are competent masters of their indigenous native language. This is a good reason to design written and oral tests. In terms of teacher training, he has claimed that the more western knowledge is taught, the less commitment there is to the communal culture, a phenomenon that is common in various zones of Latin-America (Montaluisa n.d.).

Quishpe considered the development of an indigenous literature and language as strategic clues. He also thought that intercultural training in ethno-medicine, ethnomathematics, ethno-social sciences and ethno-educational issues in general should be organized for teachers, organizational and institutional leaders and parents, all of which will reinforce indigenous knowledge and intercultural practices (Quishpe Lema 2001).

Finally, new questions have emerged and old ones still await an answer. 'How to work with the indigenous population, fundamentally Kichwa that live in cities like Quito, Guayaquil, Santo Domingo, and Machala? How to ensure that interculturality becomes the basic pattern of social relations in a pluricultural society, rather than just being an adjective to describe indigenous schools? Is there a real recovery and development of indigenous cultures and languages or is the effect rather that indigenous teachers are responsible for the 'Hispanicization' of indigenous children? How to structure bilingual intercultural education according to the peoples' and ethnic groupss' reconstruction proposals, as well as according to those places where the indigenous movement works? What role have international NGOs and organizations played in the development of bilingual intercultural education? How to take advantage of the human resources that graduate from centres of higher 
education in and outside the country (with a view to improving the conditions of intercultural education)?' (ICCI 2001).

\section{Conclusions}

When comparing MOSEIB with other solutions developed in other Latin-American countries it is clear that those countries that share a basic indigenous matrix, as well as a similar history of Spanish colonization, cope with almost the same problems, not only in educational terms but also in the way they are implementing similar policies and practices regarding intercultural bilingual education. At present 17 Latin American countries promote processes of bilingual education, bilingual intercultural education or ethno-education, some at the national level and others at only a regional or a local level. In some of those countries bilingual educational processes address all the students who speak an indigenous mother tongue. ${ }^{20}$

Although Ecuadorean intercultural bilingual education was officially recognized 17 years ago, four types of problems remain to be solved. First there is the financial issue. Ecuadorean state resources for social policies decrease every year. This severely restricts the ability to develop an adequate intercultural bilingual model. A second problem relates to this lack of resources. There are insufficient funds to increase the number of indigenous teachers. For this reason, some white-mestizo teachers are working in indigenous schools. This reality increases the tension between the two educational systems within the Ministry of Education of Ecuador. DINEIB and the Hispanic department have a competitive rather than a collaborative relationship. A third problem that MOSEIB needs to overcome is related to internal issues that result in inadequate implementation. A clear example is the lack of school textbooks in indigenous languages. Consequently, the MOSEIB methodology cannot be integrally applied. Teachers also admit that there is a lack of technical media for classroom work. Finally, there is the problem that not only white-mestizos but also some indigenous families have doubts about the legitimacy of the indigenous language and culture. These families prefer to send their children to Hispanic schools and some parents do not even allow their sons and daughters to learn and study in their indigenous language. They believe in the supremacy and usefulness of Spanish as the language of the dominant culture and consider a Hispanic education better than MOSEIB in terms of applicability to daily life.

The contribution of MOSEIB is not only to the safeguarding of a cultural and linguistic heritage. It is also about improvements in rural education, viewed as a process of reflection, discussion and experimentation, within communities and indigenous organizations. Through this curricular innovation rural society can develop its knowledge, abilities, skills, attitudes and values, while knowing its reality, understanding its problems and acting as an agent of its own future. This paper has explained how intercultural bilingual education is the result of a historical struggle by indigenous peoples for the recognition of their cultural rights. Two main actors are relevant to mention here. On the one hand, there are political and economic groups that have controlled the state apparatus since colonial times, imposing homogenizing and assimilative practices on indigenous ethnic groups with the goal of continuing their own nation state project. On the other hand, there are the indigenous and black peoples, supported by some white-mestizo organizations, ${ }^{21}$ resisting colonial and post-colonial attempts at subjugation. Official schooling 
0 inevitably reflects this power relationship. In contrast to this, indigenous peoples have also developed their own conceptions of education across history, establishing bilingual intercultural education as a proposal, which was officially recognized in 1989.

The conflictual relationships between indigenous organizations and public institutions, as well as the tension between the bilingual intercultural education and the white-mestizo Ecuadorean state, are manifestations of Ecuadorean racism and daily practices of intolerance, despite the fact that the country has officially been declared pluricultural and multilingual. Interculturality cannot be practiced if it comes from only one segment of society or if efforts at its implementation come only from minority cultures, while the dominant culture still conceives of the others as inferior. Interculturality is a task to be accomplished by all members of society. However, when the subjectivity of many of the white and white-mestizo population still sustains the colonial heritage of stereotyping, considering native Americans as ignorant and black people as lazy, the ambition of intercultural educational will be 15 hard to realize. Official educational institutions declare interculturality to be the transverse axis of the Hispanic curriculum, while inside the Ministry of Education itself the Hispanic administration does not admit indigenous policies. This situation will necessitate the compulsory implementation of effective intercultural processes in white-mestizo schools so as to allow Ecuadorean society to accept difference as a contribution to the richness of the country.

Ineffective practice at the level of the state is not an exclusive characteristic of Ecuadorean society. Structural problems are common to almost all the countries of Latin-America, even those countries where intercultural education has been established. Effective intercultural states can be considered more a utopia, rather than a reality, in spite of official declarations. Intercultural issues must be part of a wider debate, with mutual responsibility and participation by all segments of Latin-American society, including the promotion of indigenous culture to whitemestizo sectors of the population. One of the aims of MOSEIB is to support the strengthening of interculturality in Ecuadorean society. Continued intense curricular adaptation will be necessary to realize this purpose. In doing so, the new curriculum will have to respond to the communal and individual interests of indigenous peoples, including the teaching of local indigenous languages in Hispanic schools while maintaining Spanish as the language of intercultural communication.

MOSEIB works in Community Educational Centres (CECIBs), retrieving the family as the main actor in the education of their children. This diversification also relates to everyday communal practices, rituals and agricultural schedules, which are now incorporated into the organization of the school year. The indigenous ethnic groups within Ecuador have accepted the challenge of developing their own ways of learning, of preserving their culture and of implementing bilingual intercultural education against a backdrop of a globalizing world that tends to homogenize, showing little respect for cultural difference and otherness. Within this challenge processes of curricular diversification using communal learning and self-investigation are very important.

Finally, there is another challenge that must be assumed by society in general, and by whites and white-mestizos in particular. It is necessary to also incorporate local indigenous languages, ethno-educational processes and other cultural elements into the Hispanic curriculum. These curricular innovations could contribute to real 
towards the establishment of a truly intercultural society inside a multicultural country.

\section{Notes}

1. MOSEIB, Modelo del Sistema de Educación Bilingüe.

2. The descriptions 'white-mestizo' and 'mestizo' refer to those groups of the population in various Latin-American countries that are the result of a white European and an indigenous mixture. They represent the biggest segment of the Ecuadorian population, $77.42 \%$ of the total (CEPAL 2005). The term white-mestizo reflects the post-colonial attachment of mestizos to white culture, denying the indigenous (native American) matrix.

3. Native American is the name Europeans gave to the indigenous inhabitants of the continent now called America.

4. Kichwa or Quichua in Ecuador and Kechwa, Quechua or Qeshwa in Bolivia and Perú. Linguistically Kichwa is considered a dialect of the Kechwa language. In Ecuador Kichwa is the largest indigenous ethnic group, comprising 14 indigenous peoples living in the highlands and one Amazon Kichwa people living in the Amazon region, called the CaneloKichwa. According to the 2001 national statistics the Kichwa population of the highlands comprised of 595,798 persons (CEPAL 2005), according to CODENPE the Amazon Kichwa population comprised 80,000 people, in the process of expansion (CODENPE 2005).

5. The radiophonic system of the Shuar Federation, the ILV (Summer Linguistic Institute), the popular radiophonic schools of Ecuador, the indigenous schools system of Cotopaxi, the schools of the federation of communes 'Union of Natives of Ecuadorean Amazonia', the sub-programme of Kechwa alphabetization at the Research Centre for Indigenous Education (CIEI), the Chimborasoca Caipimi of Riobamba, Macac National High School, the EBI-GTZ project, the Alternative Project of Intercultural Bilingual Education of COFENIAE (PAEBIC) (Montaluisa n.d., 4).

6. The Mexican case differs from the others because in the early 1970s the Mexican state created 'the General Directorate of Indigenous Education, a dependency of the Secretariat of Public Education, whose fundamental task consists of distributing bicultural and bilingual education to the ethnic groups' (Carrasco 2003, 3).

7. The ethnic group Manta-Huancavilca-Puná, is considered by some indigenous organizations to be the fourteenth such. However, the Council for the Development of the Nationalities and Peoples of Ecuador (CODENPE) defines it as a process of reconstruction and identity precision (CODENPE 2005).

8. CIEIBs have a curricular conception that differs from Hispanic schools. CIEIBs are organized by levels rather than courses. This should allow a student to continue their own learning process according to their own development (Ramírez, cited in Garcés 2004).

9. These observations come from several years work by Alexis Oviedo, supporting different educational processes, such as teacher training, technical assistance and project management, developed in rural schools with governmental and non-governmental organizations, mainly in the provinces of Cotopaxi and Chimborazo.

10. Dr Catherine Walsh conducted a study of the textbooks for basic school. She noticed that in those textbooks indigenous and black people were often depicted as belonging to the inferior rural classes, whereas the white-mestizos are seen as respected professionals such as doctors and lawyers (from an interview with Dr Catherine Walsh, 8 March 2007).

11. Minorizacion is a process of marginalization that began with the European invasion of Latin-America, which negatively affected the indigenous societies, considered pueblos minorizados (minor societies) who are often larger in numbers than the white-mestizo 
inhabitants, as is the case in Bolivia, where $67 \%$ of its population are native Americans (Comboni and Juárez 2001).

12. In the Kajib Kobi School in Mamoestenango, Totonicapán (Guatemala) the sacred Mayan calendar (260 days) is the axis of curricular content (Moya 2001).

13. Escuela Nueva is a Colombian group of experimental schools that incorporate selfdirected learning techniques among other pedagogic innovations. Escuela Nueva started as schools in coffee production zones (Florez 2004).

14. Pedagogic mediation techniques developed by Reuben Feuerstein and Escuela Nueva have already been demonstrated to be effective (Florez 2004).

15. CONAIE's resolutions are the result of consensus among the different organizations that form it, such as CONAICE (Confederation of Indigenous and Black Organizations of the Ecuadorian Coast), ECUARUNARI (Confederation of Kichwa Nationalities and Peoples) and COFENIAE (Confederation of Indigenous Nationalities from Ecuadorian Amazonia) among others. FENOCIN is The National Federation of Farmers, Indigenous and Black Organizations.

16. There are three different regions in continental Ecuador: the coast, the highlands and the jungle. All of those regions have some native American settlements. However, the nationalities with a higher number of native American members inhabit the highlands and jungle.

17. In the 1980s it was $5.5 \%$ of the PNB, in the $1990 \mathrm{~s}, 4.7 \%$, and in the present decade it is an estimated $4.2 \%$ of PNB.

18. According to ECUARUNARI 1,200,000 Ecuadorian children between five and nine years old work, in different activities, principally in big cities.

19. The organizations are CONAIE, FENOCIN and ECUARUNARI.

20. Those countries are Mexico, Colombia, Ecuador, Bolivia and, soon, Guatemala. (López and Küper 2004, 44).

21. For example, consolidation of the indigenous movement received aid from the Communist Party of Ecuador, which supported the creation of FEI (Ecuadorian Federation of Native Americans) in the 1940s and 1950s. Early indigenous education was also supported by some catholic priests, particularly Monseñor Proaño, during the 1960s and 1970s, with projects such as Radio Schools in Kichwa, among others.

\section{References}

Carrasco, A. 2003. Educación bilingüe. Paper presented at the Centro de Investigaciones Universales, in Veracruz, México.

Comboni, S., and J. Juárez. 2001. Educación, cultura y derechos, el caso de la reforma 13 educativa Boliviana. Revista Iberoamericana de Educación, no. 27: 125-52.

Comisión Económica par América Latina y el Caribe (CEPAL). 2005. Población indígena y afroecuatorianaen Ecuador: Diagnóstico sociodemográfico a partir del censo de 2001. CEPAL. http://www.cepal.org.ar/publicaciones/xml/6/22276/LCW16-ecuador.pdf.

Confederación de Nacionalidades Indígenas del Ecuador (CONAIE). 1989. Las nacionalidades indigenas en el Ecuador: Nuestro proceso organizativo. 284 Quito, Ecuador: Ediciones Abya-Yala.

. 2005. August. Press release, Asamblea de Educación Bilingüe de la CONAIE.

Confederation of Kichwa Nationalities and Peoples (ECUARUNARI). n.d. Educación bilingüe. ECUARUNARI. http://ecuarunari.nativeweb.org/ninez/Datos_Educacion_ Intercultural_Bilingue.ppt.

Consejo Nacional de Desarrollo de las Nacionalidades y Pueblos del Ecuador (CODENPE). 2005. Nacionalidades y pueblos indígenas del Ecuador. Consejo Nacional de Desarrollo de las Nacionalidades y Pueblos del Ecuador. http://www.codenpe.gov.ec.

Dirección Nacional de Educación Bilingüe (DINEIB). 2005a. Estadísticas de las direcciones provinciales de la jurisdicción intercultural bilingüe del país. Quito, Ecuador: MEC. 
2005b. November. Press release, 13 Lenguas Indígenas Sistematizadas y Normatizadas.

EduFuturo. 2005. Biografia de Dolores Cacuango. EduFuturo. http://www.edufuturo.com/ educacion.php?c $=2457$.

Florez, A. 2004. Escuela nueva and the equality of opportunities in Colombia. Teachers College, Colunbia University. http://www.tc.edu/students/alas/2004/ANAFLOREZ.ppt.

Garcés, F. 2004 Situación de la educación intercultural bilingüe en el Ecuador. PROEIB and World Bank.

Garcés, F., and S. Guzmán. 2003. Educacionqa, Kawsayninchikmanta kawsayninchikpaq kanan Tiyan, elementos para diversificar el currículo de la nación kechwa. Bolivia: CENAQ.

Instituto Científico de Culturas Indígenas (ICCI). 2001. EIB: Iniciar una evaluación necesaria. ICCI RIMAI Bulletin 31, no. 3: 7-8.

López, L., and W. Küper. 2004. La educación intercultural bilingüe en América Latina, balances y perspectivas. ???????, ??????: PINSEIB and PROEIB Andes.

Mazaquisa, M. 2001. La política de preservar el Kichwa. Revista Yachaykuna 2: 1-6.

Ministry of Education and Culture of Ecuador (MEC). 1993. Modelo de educación intercultural bilingüe. Quito, Ecuador: MEC.

Montaluisa, L. n.d.Participación comunitaria en al educación intercultural bilingue del Ecuador. School for International Training. http://www.sit.edu/publications/docs/ops04ecuador.pdf.

Moya, R. 2000. Interculturalidad y reforma educativa en Guatemala. Revista Iberoamericana de Educación, no. 13: 129-55.

National Federation of Farmers, Indigenous and Black Organizations (FENOCIN). 2004. Propuesta de la Fenocin, frente a la situación de la EIB. FENOCIN. http:// www.fenocin.org/documentos/propuesta_EIB.htm.

Oviedo, A. 2004. Development and counter development, in rural basic education in Ecuador. Unpublished paper, CADES, Katholieke Universiteit, Leuven, Belgium.

PROEIB Andes. n.d.. Cédula de identidad multilingüe. PROEIB Andes. http://cgi.proeibandes. org/novedades/ver.php?id $=20$.

Quishpe Lema, C. 2001. Educación intercultural y bilingue. ICCI RIMAI bulletin 31, no. 3: $9-11$.

Rambla, X., and X. Bonal. 2005. Splintered multiculturalism: Three theses on multi-nation and the poly-ethnic state in the Spanish education policy. International Journal of Contemporary Sociology 40, no. 1: 75-90.

Roig, A. 1984. Humanismo en la segunda mitad del siglo XVIII. T. II Quito, Ecuador: Banco Central del Ecuador.

Schmelkes, S. 2002. La enseñanza de la lectura y escritura en contextos multiculturales. Paper 20|21 presented at the VII Congreso Latinoamericano para el Desarrollo de la Lectura y Escritura, in México.

. 2005. La interculturalidad en la educación básica. Paper presented at the Encuentro Internacional de Educación Preescolar, in México.

Sleeter, C.H., and J. Stillman. 2005. Standardized knowledge in a multicultural society. 22 Curriculum Inquiry 1, no. 35: 27-46.

Stoll, D. 2002. Pescadores de hombres o fundadores de Imperio. El ILV en America Latina. 23 Nódulo Materialista. http://www.nodulo.org/bib/stoll/ilv.htm.

40 Torres, R. 2005. Alfabetización y alfabetismo en Ecuador: Opciones para la política y la 1540 práctica. UNESCO.

Zimmerman, K. 2000. Modos de interculturalidad en la educación bilingüe. Reflexiones sobre 13 el caso de Guatemala. Revista Iberoamericana de Educación, no. 13: 113-27. 